\title{
Correction to: Industrial hemp as an agricultural crop in Ghana
}

Nana Osei Owusu*, Benedict Arthur and Emmanuel Mensah Aboagye

Correction to: Journal of Cannabis Research 3, 9(2021)

https://doi.org/10.1186/s42238-021-00066-0

Following the publication of the original article (Owusu et al. 2021), it was noted that Figs. 2 and 3 were switched.

The original article has been updated to correct the figures.

Published online: 05 June 2021

\section{Reference}

Owusu NO, Arthur B, Aboagye EM. Industrial hemp as an agricultural

crop in Ghana. J Cannabis Res. 2021;3:9. https://doi.org/10.1186/ s42238-021-00066-0.

\section{*Correspondence:}

Zhongnan University of Economics and Law, 182\# Nanhu Avenue, East Lake High-tech Development Zone, Wuhan 430073, People's Republic of China

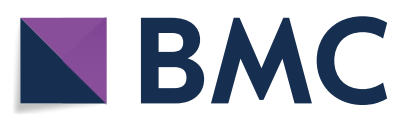

(c) The Author(s) 2021. Open Access This article is licensed under a Creative Commons Attribution 4.0 International License, which permits use, sharing, adaptation, distribution and reproduction in any medium or format, as long as you give appropriate credit to the original author(s) and the source, provide a link to the Creative Commons licence, and indicate if changes were made. The images or other third party material in this article are included in the article's Creative Commons licence, unless indicated otherwise in a credit line to the material. If material is not included in the article's Creative Commons licence and your intended use is not permitted by statutory regulation or exceeds the permitted use, you will need to obtain permission directly from the copyright holder. To view a copy of this licence, visit http://creativecommons.org/licenses/by/4.0/. 